\title{
Pencegahan Stunting Melalui Pemberdayaan Kader PKK Kecamatan Barebbo di Kabupaten Bone
}

\section{Prevention of Stunting Through Empowerment of Family Welfare Programme Cadres in Barebbo District in Bone Regency}

\author{
${ }^{1}$ Citrakesumasari, ${ }^{2}$ Yessy Kurniati, ${ }^{1}$ Aminuddin Syam, ${ }^{1}$ Abdul Salam, \\ ${ }^{1}$ Devintha Virani
${ }^{1}$ Program Studi Ilmu Gizi, Fakultas Kesehatan Masyarakat, Universitas Hasanuddin, Makassar
2 Program Studi Kesehatan Masyarakat, Fakultas Kedokteran dan Ilmu Kesehatan, Universitas Islam Negeri Alauddin, Makassar

Korespondensi: Citrakesumasari, citeku@gmail.com

Naskah Diterima: 29 Oktober 2019. Disetujui: 22 Juni 2020. Disetujui Publikasi: 10 Juli 2020

\begin{abstract}
Bone Regency has the highest prevalence of stunting under five in South Sulawesi, after Enrekang district. Family Welfare Programme (PKK) cadres are often empowered in overcoming various problems in the community. This dedication activity aims to empower PKK cadres to prevent stunting in the Barebbo District, Bone Regency. Audience The target of this training is PKK cadres in Barebb Subdistrict. The Community Service Method is to provide training to PKK cadres on stunting prevention. The training was carried out in two ways, namely by providing material on stunting and demonstrations on how to screen stunting to children through anthropometric measurements. Based on the results of the activities carried out, it appears that the training carried out has increased the knowledge of PKK cadres who were trained in the good category by $54.5 \%$. This is in accordance with established indicators of success. The training carried out effectively increased the knowledge and skills of PKK cadres in conducting anthropometric measurements. This is important in preventing stunting in infants. PKK cadres who have been trained are expected to be able to contribute significantly in screening the status of toddlers in the community.
\end{abstract}

Keywords: Toddlers, stunting, prevention, anthropometry.

\begin{abstract}
Abstrak. Kabupaten Bone menjadi kabupaten yang memiliki prevalensi balita stunting tertinggi di Sulawesi Selatan, setelah kabupaten Enrekang. Kader PKK sering diberdayakan dalam mengatasi berbagai masalah dalam masyarakat. kegiatan pengabdian ini bertujuan untuk memberdayakan kader PKK untuk mencegah terjadinya stunting di Kecamatan Barebbo, Kabupaten Bone. Khalayak Sasaran pada pelatihan ini adalah kader PKK di Kecamatan Barebbo.Metode Pengabdian yang dilakukan adalah dengan memberikan pelatihan kepada kader PKK tentang pencegahan stunting. Pelatihan tersebut dilakukan dengan dua cara, yaitu dengan pemberian materi tentang stunting dan demonstrasi tentang cara melakukan skreening stunting pada balita melalui pengukuran antropometri. Berdasarkan hasil kegiatan yang telah dilakukan, terlihat bahwa pelatihan yang dilakukan telah meningkatkan pengetahuan kader PKK yang dilatih pada kategori baik sebesar $54,5 \%$. Hal ini telah sesuai dengan indikator keberhasilan yang telah ditetapkan. Pelatihan yang dilakukan efektif meningkatkan pengetahuan dan keterampilan kader PKK dalam melakukan pengukuran antropometri. Hal tersebut penting dalam melakukan pencegahan stunting pada balita. Kader PKK yang telah dilatih diharapkan mampu berkontribusi secara nyata dalam melakukan skreening status balita di masyarakat.
\end{abstract}

Kata Kunci : Balita, stunting, pencegahan, antropometri 


\section{Pendahuluan}

Kabupaten Bone menjadi kabupaten yang memiliki prevalensi balita stunting tertinggi di Sulawesi Selatan, setelah kabupaten Enrekang. Prevalensi stunting di Kabupaten Bone di Tahun 2013 adalah 43,65\% dengan jumlah 27.700 jiwa. Tingkat kemiskinan di Kabupaten Bone di tahun 2016 adalah 10,07\% dan penduduk miskin berjumlah 75.090 jiwa. Karena itu Kabupaten Bone masuk di dalam 160 kabupaten/kota prioritas dengan 600 desa masuk dalam prioritas penanganan stunting tahap 2 di tahun 2019. Di Kabupaten Bone sendiri terdapat 10 desa, yaitu Tadang Palie, Matajang, Sugiale, Laburasseng, Tondong, Cempanigga, samaenre, Batu Putih, Hulo dan Bana. Desa Sugiale yang masuk dalam 10 desa tersebut terdapat di Kecamatan Barebbo. Maka Kecamatan Barebbo memiliki prioritas masalah penanganan stunting.

Stunting menjadi penting untuk ditangani karena menyangkut kualitas sumber daya manusia. Stunting pada anak mencerminkan kondisi gagal tumbuh pada anak balita. Stunting itu sendiri adalah kondisi gagal tumbuh pada anak berusia di bawah lima tahun akibat kekuarangan gizi kronis dan infeksi berulang terutama pada periode 1000 Hari Pertama Kehidupan (HPK). Stunting, disamping berisiko pada hambatan pertumbuhan fisik dan kerentanan anak terhadap penyakit, juga menyebabkan hambatan perkembangan kognitif yang akan berpengaruh pada tingkat kecerdasan dan produktivitas anak di masa depan. Stunting diperkirakan menurunkan produk domestik bruto sekitar 3\% per tahun (Sekwapres, 2018).

Kader PKK merupakan salah satu ujung tombak perubahan dalam masyarakat. Kader PKK sering diberdayakan dalam mengatasi berbagai masalah dalam masyarakat. Seperti masalah kesehatan. Salah satu contohnya yaitu pemberdayaan kader menyebarluaskan informasi kesehatan. Hasil dari kegiatan tersebut adalah adanya kesamaan persepsi para kader PKK mengenai upaya peningkatan derajat kesehatan melalui penyebarluasan informasi kesehatan dan penguatan partisipasinya. Dengan adanya kegiatan pemberdayaan kader PKK yang terstruktur dan komprehensif, dapat mendukung terwujudnya peningkatan derajat kesehatan masyarakat (Rodiah, Lusiana, \& Agustine, 2016)

Studi lain juga memberdayakan kader PKK dalam pencegahan Demam Berdarah. Hasil penelitian tersebut menunjukan ada peningkatan pengetahuan, sikap dan perilaku kader PKK di Kelurahan Sesetan yang mendapatkan intervensi mengenai pencegahan DBD sebelum dan setelah diberikan pemicuan. Namun, pemicuan ini belum dapat dikatakan meningkatkan pengetahuan pada kelompok intervensi jika dibandingkan kelompok kontrol karena terjadi bias histori dan bias instrumen. Sedikit berbeda dengan hasil pengukuran sikap dan perilaku yang menunjukkan adanya peningkatan efek pada kelompok intervensi dibandingkan kelompok kontrol. Disarankan kepada instansi terkait untuk mengupayakan pemicuan DBD sebagai salah satu alternatif promosi kesehatan untuk meningkatkan pengetahuan, sikap, dan perilaku dalam pencegahan demam berdarah di masyarakat. (Prasetya, 2014). Penelitian tentang pemberdayaan kader PKK dalam pencegahan DBD juga menemukan bahwa bahwa ada pengaruh pendidikan kesehatan terhadap pengetahuan ibu-ibu PKK tentang pencegahan Demam Berdarah Dengue di Desa Pucangan Kecamatan Kartasura adalah p value $=(0,000<0,05)$ dengan nilai korelasi -3,190. Dan ada pengaruh pendidikan kesehatan terhadap sikap ibu-ibu PKK tentang pencegahan Demam Berdarah Dengue di Desa Pucangan Kecamatan Kartasura adalah $p$ value $=(0,000<0,05)$ dengan nilai korelasi - 3,130 (Dwi \& Widodo, 2012). Upaya pencegahan stunting dapat dilakukan dengan memberikan pelatihan tentang pengukuran status gizi (Isni \& Dinni, 2020)

Dengan melihat permasalahan mitra, maka kegiatan pengabdian ini bertujuan untuk memberdayakan kader PKK untuk mencegah terjadinya stunting di 
Kecamatan Barebbo, Kabupaten Bone. Diharapkan melalui kegiatan ini, kader PKK dapat berpartisipasi pada upaya penurunan angka stunting di Kabupaten Bone

\section{Metode Pelaksanaan}

Tempat dan Waktu. Pelatihan Kader PKK dilaksanakan di Aula Kantor Kecamatan Barebbo pada Hari Sabtu-Ahad Tanggal 27-28 Juli tahun 2019.

Khalayak Sasaran. Khalayak Sasaran pada pelatihan ini adalah kader PKK di Kecamatan Barebbo. Pemilihan khalayak sasaran karena dari berbagai literatur telah terbukti bahwa kader PKK dapat diberdayakan dalam menyelesaikan permasalahan masyarakat.

Metode Pengabdian. Metode Pengabdian yang dilakukan adalah dengan memberikan pelatihan kepada kader PKK tentang pencegahan stunting. Pelatihan tersebut dilakukan dengan dua cara, yaitu dengan pemberian materi tentang stunting dan demonstrasi tentang cara melakukan skreening stunting pada balita melalui pengukuran antropometri

Indikator Keberhasilan. Kegiatan ini dikatakan berhasil apabila terdapat peningkatan pengetahuan kader PKK dalam kategori baik sebesar $40 \%$ pada saat sebelum dan setelah pelatihan.

Metode Evaluasi. Metode evaluasi pada kegiatan ini adalah menggunakan kuesioner pre dan post yang diberikan sebelum dan setelah pelatihan.

\section{Hasil dan Pembahasan}

\section{A. Pemberian Materi tentang Stunting}

Pelatihan pencegahan stunting pada kader PKK di Kecamatan Barebbo dilaksanakan pada hari Sabtu-Ahad, tanggal 27-28 Juli 2019. Pelatihan ini mengundang masing-masing 2 orang perwakilan kader dari setiap desa di Kecamatan Barebbo. Peserta yang hadir berjumlah 33 orang. Sebelum dilakukan pelatihan, peserta diberikan pre test untuk mengetahui pengetahuan peserta sebelum pelatihan (Gambar 2).

Pemberian materi tentang stunting dilakukan dengan metode ceramah yang dikemas dengan menarik. Pemateri berusaha menyampaikan materi sesuai dengan bahasa yang mudah dipahami oleh peserta. Setelah pemberian materi, kegiatan pelatihan dilanjutkan dengan diskusi antara peserta dan pemateri. Diskusi ini dilakukan dalam suasana yang hangat agar peserta dapat memahami materi dengan baik (Gambar 3).

Setelah dilakukan analisis terhadap hasil kuesioner ditemukan bahwa terjadi perubahan pengetahuan peserta setelah dilakukan pelatihan, hasilnya terlihat pada Tabel 1 dan Gambar 1.

Tabel 1. Perubahan Pengetahuan Peserta Pelatihan Sebelum dan Setelah dilakukan Pelatihan Stunting

\begin{tabular}{lccccl}
\hline \multirow{2}{*}{$\begin{array}{c}\text { Pengetahuan } \\
\text { tentang Stunting }\end{array}$} & \multicolumn{2}{c}{ Pre test } & \multicolumn{2}{c}{ Post test } & \multirow{2}{*}{ Perbedaan } \\
\cline { 2 - 5 } & $\mathrm{n}$ & $\%$ & $\mathrm{n}$ & $\%$ & \\
\hline Baik & 0 & 0 & 18 & 54,5 & Meningkat $54,5 \%$ \\
Cukup & 0 & 0 & 11 & 33,3 & Meningkat 33,3\% \\
Kurang & 33 & 100 & 4 & 12,1 & Menurun $87,9 \%$ \\
\hline
\end{tabular}

Berdasarkan tabel 1 terlihat bahwa pengetahuan peserta tentang stunting sebelum dilakukan pelatihan, semuanya masih dalam kategori kurang. Setelah dilakukan pelatihan, pengetahuan peserta meningkat menjadi $54,5 \%$ dalam kategori baik dan 33,3\% dalam kategori cukup. Sedangkan pengetahuan stunting dalam kategori kurang menurun menjadi $12,1 \%$. 


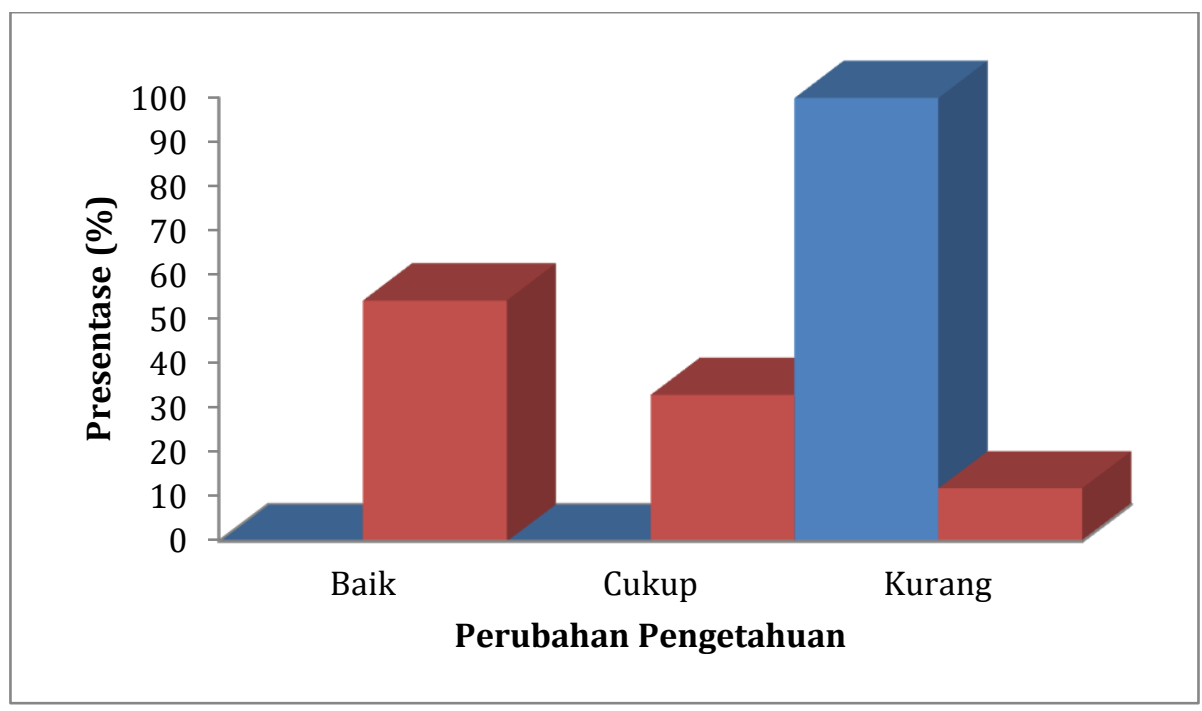

Gambar 1. Grafik perubahan pengetahuan peserta sebelum dan setelah pelatihan

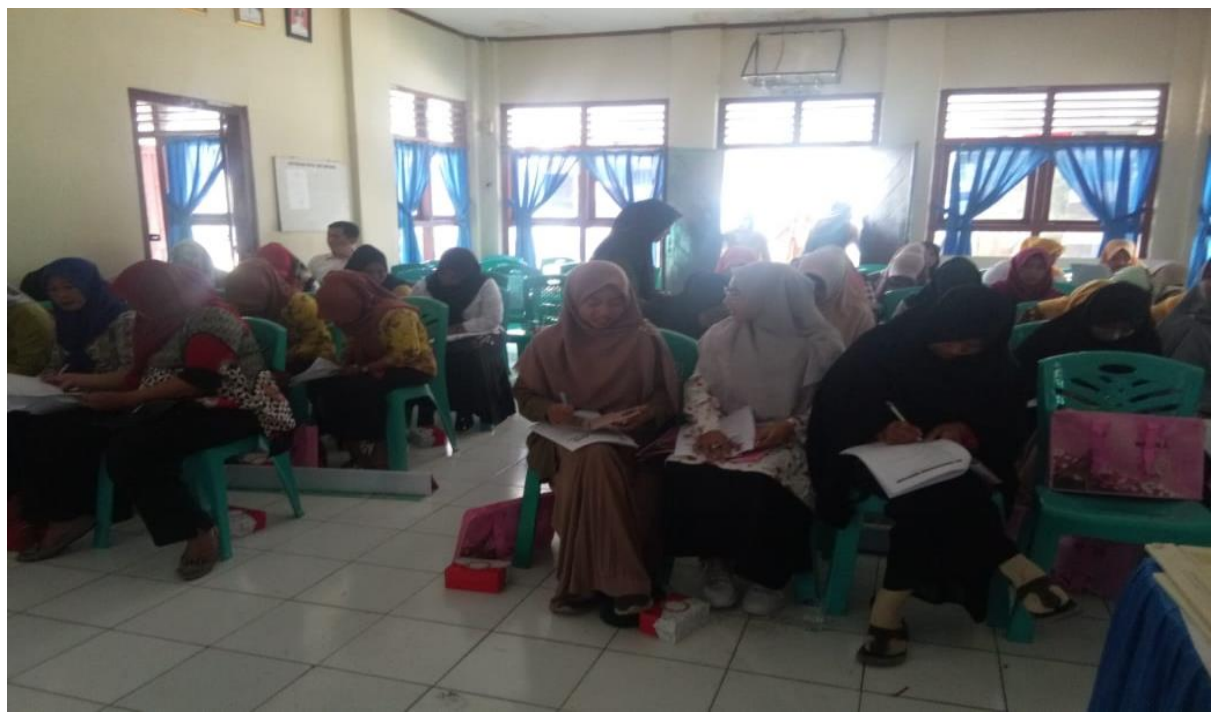

Gambar 2. Pelaksanaan Pre test

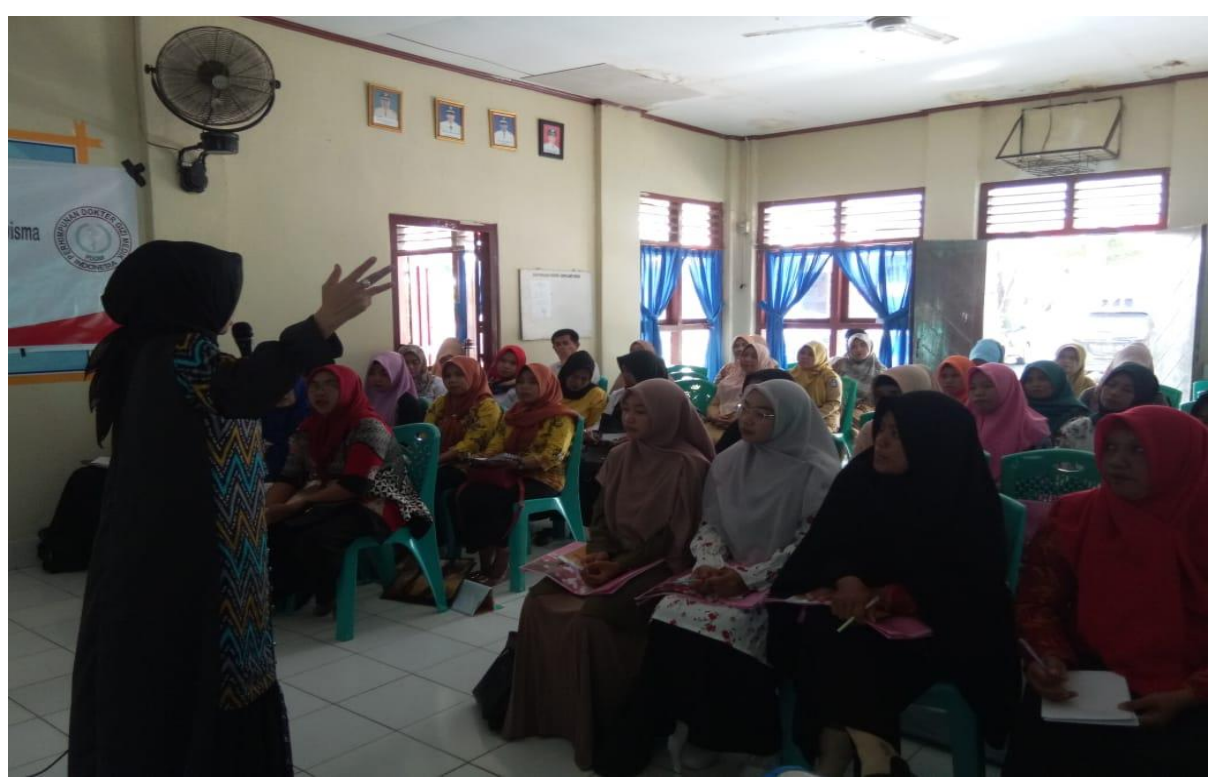

Gambar 3. Pemberian Materi tentang Stunting 


\section{B. Demonstrasi Pengukuran Status Gizi Balita}

Setelah dilakukan pemberian materi tentang stunting, peserta kemudian diberikan demonstrasi cara mengukur status gizi pada balita dengan menggunakan alat pengukur panjang badan dan berat badan balita. Demonstrasi dilanjutkan dengan memasukkan hasil pengukuran tersebut kedalam tabel untuk menentukan apakah balita mengalami stunting atau tidak. Hasil pengukuran ini dibedakan antara balita laki-laki dan balita perempuan. Pemateri berusaha melakukan demonstrasi dengan melibatkan peserta, sehingga peserta lebih aktif. Hal tersebut diharapkan dapat meningkatkan pemahaman dan keterampilan peserta dalam melakukan pengukuran antropometri pada balita (Gambar 4 dan 5).

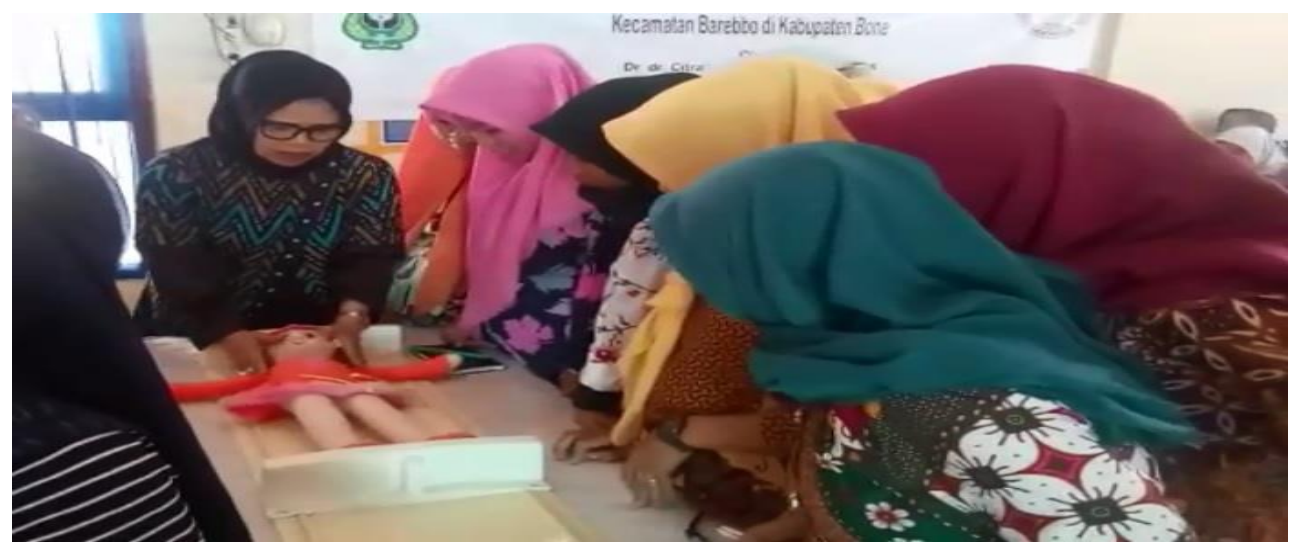

Gambar 4. Pemateri menunjukkan cara melakukan pengukuran panjang badan balita

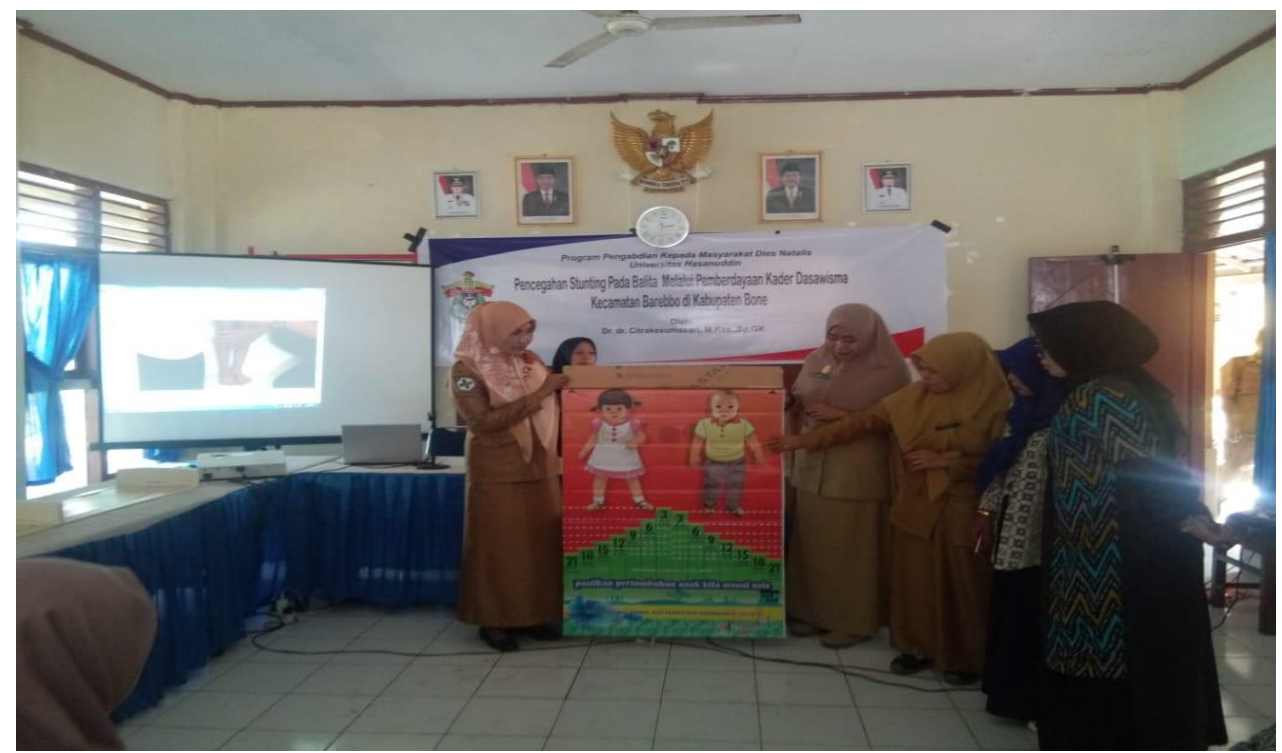

Gambar 5. Demonstrasi tentang cara memasukkan data pengukuran antropometri untuk menentukan status gizi balita

\section{Keberhasilan Pelatihan dan Pendampingan Dalam Meningkatkan Kemampuan Kader Dusun Untuk Melakukan Skreening Sindrom Metabolik}

Berdasarkan hasil kegiatan yang telah dilakukan, terlihat bahwa pelatihan yang dilakukan telah meningkatkan pengetahuan kader PKK yang dilatih pada kategori baik sebesar 54,5\%. Hal ini telah sesuai dengan indikator keberhasilan yang telah ditetapkan. Yaitu pelatihan dikatakan berhasil apabila mampu meningkatkan pengetahuan responden pada kategori baik sebesar 40\%. 


\section{Kesimpulan}

Pelatihan yang dilakukan efektif meningkatkan pengetahuan dan keterampilan kader PKK dalam melakukan pengukuran antropometri. Hal tersebut penting dalam melakukan pencegahan stunting pada balita. Kader PKK yang telah dilatih diharapkan mampu berkontribusi secara nyata dalam melakukan skreening status balita di masyarakat

\section{Ucapan Terima Kasih}

Penulis mengucapkan terima kasih kepada Bupati Bone, Camat Barebbo atas kerjasama yang diberikan. Penulis juga mengucapkan terima kasih kepada seluruh peserta pelatihan yaitu kader-kader PKK dari Kecamatan Barebbo. Terakhir, penulis mengucapkan terima kasih kepada LPPM Unhas untuk bantuan dana yang diberikan bagi pelaksanaan kegiatan melalui Hibah Pengabdian Dies Natalis Tahun 2019

\section{Referensi}

Barebbo, K. (2019). Barebbo.blogspot.com. Dipetik Maret 3, 2019

BPS. (2018). Kabupaten Bone Dalam Angka 2018, Bone

Dwi, A. \& Widodo, A. (2012). Pengaruh Pendidikan Kesehatan Pada Ibu-Ibu Kader

Isni, K. \& Dinni, S.M. (2020). Pelatihan Pengukuran Status Gizi Balita Sebagai Upaya Pencegahan Stunting Sejak Dini pada Ibu di Dusun Randugunting, Sleman, DIY. Jurnal Panrita Abdi, 4(1), 60-68.

Pemberdayaan Keluarga Dan Kemasyarakatan (PKK) Dalam Mengubah Pengetahuan Dan Sikap Tentang Pencegahan Demam. Surakarta: Tesis Muhammadiyah.

Pemda Bone. (2013). RPJMD Kabupaten Bone Tahun 2013-2018, Bone

Dinas Pendidikan (2014). Profil Pendidikan Kabupaten Bone, Bone

Prasetya, W. (2014). Pengaruh Pemicuan Masalah Demam Berdarah Berbasis Masyarakat terhadap Pengetahuan, Sikap, dan Perilaku Pencegahan DBD pada Kader PKK di Kelurahan Sesetan Tahun 2013. Neliti .

Rodiah S, Lusiana E, \& Agustine M. (2016). Pemberdayaan Kader PKK dalam Usaha Penyebarluasan Informasi Kesehatan di Kecamatan Jatinangor Kabupaten Sumedang. Dharmakarya .

Sekwapres. (2018). Stranas Percepatan Pencegahan Anak Kerdil tahun 2018-2024, Jakarta

Penulis:

Citrakesumasari, Program Studi Ilmu Gizi, Fakultas Kesehatan Masyarakat, Universitas Hasanuddin, Makassar. E-mail: citeku@gmail.com

Yessy Kurniati , Program Studi Kesehatan Masyarakat, Fakultas Kedokteran dan Ilmu Kesehatan, Universitas Islam Negeri Alauddin, Makassar. E-mail: yessy.kurniarti@gmail.com

Aminuddin Syam, Program Studi Ilmu Gizi, Fakultas Kesehatan Masyarakat, Universitas

Hasanuddin, Makassar. E-mail: amin.gzuh@gmail.com

Abdul Salam, Program Studi Ilmu Gizi, Fakultas Kesehatan Masyarakat, Universitas Hasanuddin, Makassar. E-mail: salamgiziuh@gmail.com

Devintha Virani, Program Studi Ilmu Gizi, Fakultas Kesehatan Masyarakat, Universitas Hasanuddin, Makassar. E-mail: dvirani@gmail.com

Bagaimana men-sitasi artikel ini:

Kesumasari, C., Kurniati, Y., Syam, A., Salam, A., \& Virani, D. (2020). Pencegahan Stunting Pada Balita Melalui Pemberdayaan Kader PKK Kecamatan Barebbo Kabupaten Bone. Jurnal Panrita Abdi, 4(3), 322 - 327. 